\title{
Covid-19: Are chest compressions an aerosol generating procedure or not?
}

\author{
Zack AS Hassan foundation year 2 doctor \\ Western General Hospital, NHS Lothian, Edinburgh EH4 2XU, UK
}

The central problem of doctors in the west Midlands being told not to start chest compressions in patients who are in cardiac arrest if they have suspected or diagnosed covid-19 is a lack of evidence on whether chest compressions are an aerosol generating procedure (AGP) that can spread coronavirus. ${ }^{1}$

In 2007, the World Health Organization recommended cardiopulmonary resuscitation (CPR) was an AGP. CPR was then delisted after a systematic review failed to show a statistically significant relation. ${ }^{23}$ The $95 \%$ confidence interval ranged from 0.2 to 11.3 , however, so the evidence was clearly underpowered and of low quality. WHO's scientific brief on covid-19 notably included CPR in the list of AGPs, but did not specify which components are aerosol generating. ${ }^{4}$ Controversially, there are two mutually exclusive schools of thought on how to interpret this.

One, comprising Public Health England (PHE) and Health Protection Scotland (HPS), recommends starting compression only CPR without FFP3 masks, stating there is no evidence to suggest it is an AGP. ${ }^{25}$ The other, comprising the Resuscitation Council (UK) and the US Centers for Disease Control and Prevention, states that compression only CPR is an AGP, ${ }^{6}$ and that the theoretical risk of increased transmission not yet shown by current evidence should be mitigated by wearing FFP3 masks. Both schools have faults. The Resuscitation Council's advice may lead to trusts discouraging staff from starting CPR because of shortages of FFP3 masks, while PHE's advice may put staff at risk and is strongly opposed by the BMA. Intriguingly, PHE's advice first included CPR as an AGP then omitted reference to it before stating its current position, leading some to suggest any changes were motivated by a desire to ration PPE. ${ }^{?}$

Amid widespread local variation, staff with a dissenting opinion to their trust have been left in the lurch. Last month, the
International Liaison Committee on Resuscitation's pre-publication systematic review strongly supported the Resuscitation Council's position. ${ }^{8}$ Since the government's scientific advice relied on the older review, ${ }^{9}$ it remains to be seen whether PHE will take this new evidence into account.

Competing interests: None declared.

Full response at: www.bmj.com/content/368/bmj.m1282/rr-1.

Mahase E, Kmietowicz Z. Covid-19: Doctors are told not to perform CPR on patients in cardiac arrest. BMJ 2020;368:m1282. 10.1136/bmj.m1282 32224494

2 Health Protection Scotland, NHS National Services Scotland. Aerosol generating procedures. https://hpspubsrepo.blob.core.windows.net/hps-website/nss/2893/documents/ 1_tbp-Ir-agp-v1.1.pdf.

3 Tran K, Cimon K, Severn M, Pessoa-Silva CL, Conly J. Aerosol generating procedures and risk of transmission of acute respiratory infections to healthcare workers: a systematic review. PLoS One 2012;7:e35797. 10.1371/journal.pone.0035797 22563403

4 World Health Organization. Modes of transmission of virus causing covid-19: implications for IPC precaution recommendations. 29 March 2020. www.who.int/news-room/ commentaries/detail/modes-of-transmission-of-virus-causing-covid-19-implications-foripc-precaution-recommendations.

5 Health Protection Scotland, NHS National Services Scotland. Rapid review of the literature: assessing the infection prevention and control measures for the prevention and management of COVID-19 in healthcare settings. 20 April 2020. www.hps.scot.nhs.uk/ web-resources-container/rapid-review-of-the-literature-assessing-the-infection-preventionand-control-measures-for-the-prevention-and-management-of-covid-19-in-healthcaresettings.

6 Chan TCY, Li H, Lebovic G, et al. Identifying locations for public access defibrillators using mathematical optimization. Circulation 2013;127:1801-9.

10.1161/CIRCULATIONAHA.113.001953 23553657

7 Newman M. Covid-19: doctors' leaders warn that staff could quit and may die over lack of protective equipment. BMJ 2020;368:m1257. 10.1136/bmj.m1257 32217522

8 Couper K, Taylor-Phillips S, Grove A, Freeman K, Osokogu O, Court R. Covid-19 infection risk to rescuers from patients in cardiac arrest. International Liaison Committee on Resuscitation. 2020. https://costr.ilcor.org/document/covid-19-infection-risk-to-rescuersfrom-patients-in-cardiac-arrest.

9 New and Emerging Respiratory Viruses Advisory Group. NERVTAG consensus statement on cardiopulmonary resuscitation as an AGP. 2020. https://app.box.com/s/ 3lkcbxepqixkg4mv640dpvvg978ixjtt/file/657486851975.

Published by the BMJ Publishing Group Limited. For permission to use (where not already granted under a licence) please go to http://group.bmj.com/group/rights-licensing/ permissions 